\title{
Effectivity of Lime Peel Decoction (Citrus Aurantifolia Swingle) on Osteoblast and Osteoclast Numbers in the Process of Bone Healing Post-Extraction on White Rat (Rattus Norvegicus) Wistar Strain
}

\author{
Azimah Nurin Nafilah \\ Student \\ Faculty of Dentistry, Universitas Brawijaya \\ Malang, Indonesia \\ provesorsejati.zira@gmail.com
}

\author{
Nurul Istichomah \\ Student \\ Faculty of Dentistry, Universitas Brawijaya \\ Malang, Indonesia
}

\begin{abstract}
Prolong teeth loss due to dental extraction causes interference with the Temporomandibular Joint (TMJ), speech impairment and psychological aspects of aesthetics. For the fulfillment of general, dental and oral health, denture is needed to maintain necessary function of chewing. Generally, after tooth extraction, the patient will inquire the duration needed for denture fabrication, because the bone healing process takes a long time, so the denture fabrication is delayed. The current solution is the usage of chemical drugs to cope with injuries which have side effects, it is necessary to develop herbal medicine that can accelerate healing of bones. Potential herbal remedies include lime peel decoction (Citrus aurantifolia Swingle). Post-extraction wound healing consists of inflammatory stage, repair stage, and remodeling stage. For denture fabrication, the socket or periodontal tissue must go through the remodeling phase to obtain strong and retentive bone support. Remodeling phase indicators include osteoblasts and osteoclasts. The bone will undergo continuously dynamic process of remodeling, where osteoblasts play a role in formation and osteoclasts in resorption. Citrus aurantifolia Swingle contains flavonoid and vitamin $C$ can inhibit differentiation of osteoclasts so as to have an effect on increasing number of osteoblasts and accelerate the occurrence of bone healing. The extracted lime peel decoction was given to white rat (Rattus norvegicus) for 21 days and observes osteoblast and osteoclast cells. Lime peel decoction (Citrus aurantifolia Swingle) is effective towards post-extraction bone healing in white rats (Rattus norvegicus) wistar strains.
\end{abstract}

Keywords-decoction of lime peel (Citrus aurantifolia Swingle, osteoblast, osteoclast, denture, remodeling

\section{INTRODUCTION}

Tooth extraction leads to injury to the oral tissues, then a healing process that is a complex and dynamic process and involves the interaction of different types of cells and molecules [1,2]. The wound healing process consists of interconnected phases one and another of hemostasis, inflammation, proliferation and tissue remodeling [3]. In practice, the time required for healing is much questioned by the public as it relates to making artificial teeth after the retraction. But there is no known scientifically proven healing time to answer the question, using only estimates.

Currently the development of pharmaceutical technology has focused the world's attention on materials derived from nature because it is relatively safe compared to chemical drugs [4]. One of the potential herbs for wound healing is lime (Citrus aurantifolia) where the skin and fruit have active substances that can accelerate the healing process of wounds and bone [5,6]. Seeing this potential writer initiated the paper to find out the extent of the effect of lime peel decoction (Citrus aurantifolia) against the amount of osteoblasts and osteoclasts alveoli in white rats (Rattus norvegicus) strain wistar post extraction tooth.

\section{A. Tooth extraction}

\section{LITERATURE REVIEW}

Tooth extraction is a procedure that can cause damage to the tooth socket part including periodontal tissues such as gingival, cementum, periodontal ligament and alveolar bone. The inflammatory process becomes an important process in dental extraction followed by bone remodeling and tissue repair. The wound healing process requires sterile and antiinflammatory, antibacterial, anti-mycotic, antiseptic, and anti-parasitic areas to speed up the process [7].

\section{B. Wound healing}

Wound is a state of missing or disconnected continuity of a network [1]. When blood vessels are cut off, some components such as histamine, bradykinin, serotonin and prostaglandins will be released by damaged platelets [8]. Furthermore, the body will react to the wound is a healing process that is a complex and dynamic process and involves the interaction of various 
types of cells and molecules [3]. Injuries commonly occurring in the oral cavity are caused by surgery or trauma and wound healing can occur much faster than skin lesions with minimal scar formation $[3,9]$. Injuries to oral mucosa contain fewer immune mediators, blood vessels, and profibrotic mediators but have more bone marrow cells, higher rates of re-epithelization and faster fibroblast proliferation than skin lesions [3].

Generally, the wound healing process consists of three phases, namely the inflammatory phase, the proliferation phase, and the remodeling phase. The inflammatory phase begins as soon as the tooth is extracted for 3-5 days. Signs such as rubor, calor, tumor, dolor, and typolaesa usually appear in this phase. Production of histamine, quinine, and prostaglandin by leucocytes increases [10]. The proliferation phase lasts for 3 days to 3 weeks. In this phase, tooth sockets are filled with inflammatory cells, fibroblasts, collagen matrices, and hyaluronic acid to prepare for granulation tissue formation [11]. The remodeling phase is also called the maturation phase. In this phase, the osteoblasts will reagent with the intracellular substance of bones containing collagen to form new fibers-as well as collagen. The activity of osteoblasts and osteoclasts will convert immature bones into mature bones. The bones become stronger so that osteoclasts can penetrate tissue and debris in the wounded area followed by osteoblasts that will fill the space between new bones. This process takes months or even years until the alveolar bone returns to its original form [12].

\section{Bone remodelling process}

One of the causes of damage to the tooth socket is the action of tooth extraction. After damage, the stages of wound healing occur automatically and bones will start the process of osseointegration, stimulating new bone formation through modeling and remodeling. Modeling is an early process that includes early changes in bone formation and remodeling is a process whereby resorption of disposal bone and replacing it with newly formed bone. The osteointegration process stimulates the new bone formation that occurs naturally and during healing in osteotomy defects. Bone is constantly undergoing remodeling, which is a complex process that accompanies bone resorption on some surfaces, followed by a bone formation phase. The order of bone remodeling under normal circumstances is always the same: bone resorption by osteoclasts, reversal phase, followed by bone formation where osteoblasts acts to repair defects [13].

\section{Osteoclast}

Osteoclast is a large multinuclear cell with a diameter of $100 \mu \mathrm{m}$ with 10-12 nuclei contained therein along the bony surface where resorption, remodeling, and bone repair occur. Osteoclasts derive from macrophage-granulotic precursors present in the bone marrow that enters into the blood stream as monocytes. Its main function is to resorb bone during remodeling. Osteoclast is often present in a shallow curve of an enzymatic, eroded or eroded bone called lacuna howship. Morphologically, multinucleated giant cells must be attached to the bone and show a creased boundary to be called an osteoclast. This area is an osteoclast attachment to the bone matrix and forms a microenvironment for bone resorption processes. The attachment zone between the creased and bone boundary, isolating the surface of the microenvironment, provides additional enzymes, such as anhydrous carbonic acid to lower $\mathrm{pH}$, and build a solution from the inorganic matrix of calcium and phosphatase which exposes the organic matrix to this proteolytic enzyme. This creased boundary builds up the resorption and osteoclast regions where enzymatic destruction occurs on the bony surface. Osteoclasts produce acids, collagenases, and other proteolytic enzymes that attack the bone matrix and liberate the calcifying base substance and are actively involved in clearing debris that occurs during bone resorption [14].

\section{E. Osteoblast}

Osteoblasts are mononuclear cells that attach to the surface of the bone and form new bone structure. They produce type I collagen and other osteoid component matrices and they also mineralize the osteoid with hydroxyapatite. The growing child has more osteoblasts than the elderly. In elderly women, osteoblasts may increase in number to compensate for increased bone residence due to lack of estrogen. In elderly men, osteoblast activity may decrease probably due to decreased Insulin-like Growth Factor 1 (IGF-1) and testosterone. Marker bone formation can be measured in serum [14].

\section{F. Lime peel deco}

Generally, the public knowsa lot of its vitamin C content is large enough to reduce or decrease the differentiation of osteoclasts [15]. A study on the effectiveness of vitamin $\mathrm{C}$ administration on osteoblast cell activity after tooth extraction in male wistar rats, said that vitamin $\mathrm{C}$ has the ability to stimulate osteoblast growth and differentiation so that it can accelerate the process of wound healing after tooth extraction [16].

In addition, lime also contains saponin and flavonoid compounds namely hesperedin (hesperitin 7 routosides), tangeritin, naringin, eriocitrin, eriocitrocide. Every 100 grams of lime fruit contains; vitamin C $27 \mathrm{mg}$, calcium $40 \mathrm{mg}$, phosphorus $22 \mathrm{mg}$, carbohydrate $12.4 \mathrm{mg}$, vitamin B $10.04 \mathrm{mg}$, iron 0.6 $\mathrm{mg}$, fat $0.1 \mathrm{mg}$, calories $37 \mathrm{mg}$, protein $0.8 \mathrm{mg}$ water $86 \mathrm{~g}$, other substances up to $100 \%$ [5].

Flavonoids are able to inhibit osteoclasts thus accelerating the process of bone regeneration [6]. Flavonoids can inhibit osteoclast differentiation and bone resorption. In addition, the application of flavonoids can also reduce the pain that arises after dental extraction by inhibiting the path of cyclooxygenase and phospholipase A2 so that prostaglandin synthesis will be reduced [15]. 


\section{DISCUSSION}

The patient is often advised to get prosthesis in order to restore chewing, speech, and aesthetic functions after extraction of teeth. Condition of patients for prosthesis after extraction of teeth, among others, that there has been wound healing and the formation of edentulous tissue. The wound healing process consists of the coagulation phase, the inflammatory phase, the proliferation phase and the remodeling phase. Wound healing in the post-extraction socket is said to be perfect when the dental alveoli is filled with thick trabecular bones with its medullary canal [17]. In practice, many people are asking how long it takes to manufacture denture after an extraction. But there is no scientifically proven time to answer that question, using only estimates in answering it and anti-inflammatory drugs are usually given to speed the healing process. Nonsteroidal anti-inflammatory drugs can be used topically as a complementary therapy to treat inflammatory processes and clinical signs of disease [18]. But this drug has side effects such as the digestive tract (nausea, vomiting, diarrhea, gastric bleeding, and dyspepsia) as well as side effects on the kidneys. Currently the development of pharmaceutical technology is focusing the world's attention on materials derived from nature because it is relatively safe compared to chemical drugs [4].

Lime peel has an important role for health. Lime peel contains a very useful component to lower cholesterol [19]. Lime peel contains flavonoid compounds naringin, hesperidin, naringenin, hesperitin, routine, nobiletin, and tangeretin [20]. Flavonoids are the largest group of polyphenol compounds that can work as antioxidants, and also as antibacterial by denaturing bacterial cell proteins and damaging bacterial cells [19]. Flavonoids are able to inhibit osteoclasts so as to speed up the process of bone regeneration. Flavonoids can inhibit osteoclast differentiation and bone resorption $[6,15]$. Vitamin $\mathrm{C}$ is one of the nutrients that play a role in wound healing. Vitamin $\mathrm{C}$ is an essential cofactor for synthesizing collagen, proteoglycans and other intracellular matrix organic tissue components [21]. Vitamin C deficiency can lead to the formation of abnormal collagen fibers and changes in intracellular matrix that cause skin lesions, poor adhesion of endothelial cells and reduced strain strength of connective tissue [22]. Research on the effectiveness of Vitamin $\mathrm{C}$ administration to post tooth extraction osteoblast activity in male wistar rats, said that Vitamin $\mathrm{C}$ has the ability to stimulate osteoblast growth and differentiation so as to accelerate the process of wound healing after tooth extraction [16]. So that with the substances on this lime peel, wound healing and bone remodeling can be accelerated and knowing the exact time. The active substance on the lime peel decoction can accelerate the process of wound regeneration, so that healing increases and can be made more rapidly.

As a conclusion in this literature review, provision of lime peel decoction (Citrus aurantifolia) has the potential to accelerate wound healing this is seen with the amount of osteoblasts and osteoclasts alveol in white rats (Rattus norvegicus) strain wistar post extraction tooth. Further research is needed related to the dosage of lime decoction (Citrus aurantifolia) to be effective and cooperation from various disciplines.

\section{ACKNOWLEDGMENT}

Acknowledgments are addressed to the Dentistry Faculty of Universitas Brawijaya.

\section{REFERENCES}

[1] Masir, O. Guy, M. Manjas, A. E. Putra, S. Agus, "Pengaruh cairan cultur filtrate fibroblast (CFF) terhadap penyembuhan luka: penelitian eksperimental pada rattus novergicus galur wistar," Jurnal Kesehatan Andalas, vol. 1(3), pp. 112-117, 2012.

[2] H.L. Orsted, D. Keast, L.F. Lalande, M.F. Megie, "Basic Principles of Wound Healing: An Understanding of the basic physiology of wound healing provides the clinician with the framework necessary to implement the basic principles of chronic wound care," Wound Care Canada, vol. 9(2), pp. 4$12,2011$.

[3] J.E. Glim, M.V. Egmond, F.B. Niessen, V. Everts, R.H. Beelen, "Detrimental dermal wound healing: What can we learn from the oral mucosa," International Journal of Tissue Repair and Regeneration, vol. 21(5), pp. 648 660, 2013.

[4] Rostiny, et al., "Spirulina chitosan gel induction on healing process of Cavia cobaya post extraction socket," Dental Journal, vol. 47(1), pp. 20, 2014.

[5] D.S. Prasetyono. A-Z Daftar Tanaman Obat Ampuh di Sekitar Kita, Ed. Ke-1, jogjakarta: Flashbooks, 2014.

[6] E.M. Tan, N.S.Y. Chew, E.L. Yong. "Icaritin, A Prenylated Flavonoid, Inhibits Osteoclast Differentiation And Function In Vitro," Osteoporosis International, vol. 26, pp. 236, 2015.

[7] R.G. Topazian, M.H. Goldberg, J.R. Hupp. Oral and maxillofacial infections, $4^{\text {th }}$ ed. USA: Elsevier Saunders; 2002. pp. 2-157.

[8] H. Guyton H. Textbook of medical physiology, $13^{\text {th }}$ ed., US: Elsevier, 2015. pp. 434; 457.

[9] H. Larjava. Oral wound healing: cell biology and clinical management. British, UK: John Wiley and Sons, 2012. pp. 1.

[10] J.R. Hupp. Wound repair. In: Contemporary oral and maxillofacial surgery, $5^{\text {th }}$ ed., St. Louis: Mosby Yearbook Inc; 2008. pp. 47-54.

[11] J. Peterson, Larry, Oral and maxillofacial surgery. $2^{\text {nd }}$ ed., St. Louis: C.V. Mosby Company, pp. 116-117.

[12] J.R. Lieberman, G.E. Friedlaender. Bone regeneration and repair. New Jersey: Humana Press, 2005. pp. 6-9, 21-4.

[13] R.J. Foncesa RJ. Oral and maxillofacial surgery. Philadelphia: Saunders, 2000.

[14] S.D.C. Thomas, "Bone turnover markers," Aust. Prescr., vol. 35, pp. 156-158, 2012.

[15] E.M.A Marbun, M. Restuati, "Pengaruh ektrak etanol daun buas-buas (Premna pubescens Blume) sebagai antiinflamasi pada edema kaki tikus putih (Rattus norvegicus)," J. Biosains, vol. 1(3), pp. 107-112, 2015.

[16] J.R. Koraag, "Efektivitas perasan daun pepaya terhadap jumlah osteoblas pasca pencabutan gigi pada tikus wistar jantan," PHARMACON, vol. 4(4), 2015.

[17] J.M. Kanczler, R.O Oreffo, "Osteogenesis and angiogenesis: the potential for engineering bone," vol. 2(15), pp. 100-14, 2008.

[18] M.A Lynch, V.J. Brigman, M.S. Greenberg. Burket's oral medicine. Diagnosis and treatment, $8^{\text {th }}$ ed., pp. 163-208.

[19] M. Astawan. Bersahabat Dengan Kolesterol, Solo: Tiga Serangkai, 2004.

[20] Choi, Soo-Youn, H.C. Ko, et al., "Correlation between flavonoid content and the NO production inhibitory activity of peel extracts from various citrus fruits," Biol. Pharm. Bull., vol. 30(4), pp.772-778, 2007.

[21] D. Mackay, A.L Miller, "Nutritional support for wound healing," Alternative Medicine Review, vol. 8(4), pp. 359-360, 2003. 
[22] Yunanda, Visa, T. Rinanda, "The activity of topical extract of onions (Allium cepa) on wound healing process in mice (Mus musculus)," J. Veteriner, vol. 17(4), pp. 606-614, 2016. 